\title{
The Future Viability of the Current Antitrust Treatment of Vertical Restraints
}

\author{
Sanford M. Litvack $\uparrow$
}

It seems to me that there really are but two questions posed on the subject of vertical restraints. First, is the current state of the law of vertical restraints likely to change? And second, how does one evaluate the present posture in any event? As to whether the law is likely to change, although I do not pretend to be a historian or a scholar on the point, I believe the antitrust laws, like most legislation, were born out of the political and economic climate prevailing at the time.

While I will not attempt to debate whether there are or are not political values that ought to be applied im antitrust cases, the very plain truth is that anyone who thinks that legislation is not the product of prevailing politics has not been to Washington. Thus, to believe that the mood and swing in antitrust is not a result or reflection, at least in part, of the political and economic chimate of this country is to ignore a very definite reality. If one is going to predict the future in this area of the law, therefore, one should be mindful of the changing political mood and views of the country. For instance, will we look for more or less government participation? Will we favor protectionism or a reduction in import barriers? The answers to those questions and others will tell us a great deal about the course of antitrust law.

As recently as 1980, Senator Kennedy, who then headed the Judiciary Committee, introduced legislation to put restraints on acquisitions of certain sizes or in certain industries. Six or seven years later, we find that notion incredible as we read about merger after merger in the daily press. But the reality is that in the blink of an eye the national mood and economy have changed, and so has antitrust enforcement.

In looking forward-and focusing on the area of vertical restraints-I do not think that in the short-to-medium term there is likely to be a major change in the law. I do not see anything on the horizon that is likely to alter the law in the vertical restraint area-if for no other reason than that a large number of judges were appointed dur-

$\dagger$ Partner, Dewey, Ballantine, Bushby, Palmer \& Wood, New York, N.Y. B.A. 1956, University of Connecticut; LL.B 1959, Georgetown University. Assistant Attorney General, Antitrust Division, 1980-81. 
ing the Reagan administration. Indeed, the small likelihood of any significant alteration in the law is not due merely to the large number of judges appointed (because President Carter also appointed a significant number of judges), but to the greater care by this administration to be certain that its appointments meet with the ideology of the administration. While I will not comment on the correctness of the administration's ideological screening, the fact is indisputable. Change is far off.

Nor do I believe that government enforcement is going to change materially in the area of vertical restraints. First, it is important to recognize that there has not been a great deal of government enforcement in the vertical restraints area for the last twenty years. Second, government resources are increasingly going to be stretched, and hence vertical enforcement will necessarily take a back seat. However, there may well be a change in the government's rhetoric with regard to vertical restraints. We have gone through a time when the administration, and the Antitrust Division specifically, has eschewed the notion that there could, would, or should be anything wrong with vertical restraints. If there were a different administration over the next four to eight years, the rhetoric in that regard might well change. While that would not change the law, it would alter the day-to-day life of most lawyers since it would certainly affect the attitudes of the business community.

That leads me to the second question posed: How does one evaluate the present posture? When all is considered, the state of affairs in the vertical area is not too bad. I have no quarrel, nor does virtually anyone else, with the notion that the rule of reason test would and should apply to non-price vertical restrictions. Professor Baxter argues that such a rule means virtual per se legality, ${ }^{1}$ and I would probably agree. On the other hand, vertical restraint cases are still filed, and while they are difficult cases from the plaintiff's standpoint, the law permits the airing and development of facts that may or may not lead to a finding of unreasonableness.

I recognize a certain logical tension, if not outright inconsistency, between the approach taken in Continental T.V., Inc. v. GTE Sylvania, $I n c{ }^{2}$ regarding non-price restraints and the per se rule applied in the vertical price area. Nonetheless, I continue to opt for the per se rule at least with regard to minimum resale price maintenance. I do not believe that the Court is going to change that, as Monsanto Co. v. Spray-Rite Service Corp. ${ }^{3}$ proves. The basic reason the per se rule continues to be accepted is that those like Baxter, who would argue against it, have not made their case outside of an economic laboratory.

1. Baxter, The Viability of Vertical Restraints Doctrine, 75 CALIf. L. REv. 933 (1987).

2. 433 U.S. 36 (1977).

3. 465 U.S. 752 (1984). 
My concern is that most of what I have seen in the resale pricefixing area are situations in which either initially or eventually most resale price maintenance schemes are hatched, nurtured, or preserved by the retailers in a cartel-like manner. That is the reality. Does it make economic sense? Perhaps, but that does not alter the day-to-day business experience. Hence, it is important and useful to maintain the per se rule.

Before I conclude, I should clearly say that I do not believe that all is wonderful in the world of antitrust; I see some important problems. For instance, while Earl Pollock takes comfort from the Supreme Court's statement in Monsanto that a plaintiff must prove a "conscious commitment to a common scheme," I am more dubious. I recently tried a retail price-fixing case and can tell you how difficult it is to explain to a jury what that supposedly simple phrase means. When we worked over the instructions with the court, counsel correctly argued that the instructions should state exactly what the Supreme Court said-a conscious commitment to a common scheme. But the difficulty the jury had in comprehending such a concept was obvious. We must better articulate these rules if we expect the system to work.

And that leads me to the final point. Professor Baxter suggests a system whereby the plaintiff would have the initial burden of convincing a trier of fact of the "plausibility" of the restraint and of establishing that the restraint could or would have an impact. ${ }^{5}$ Then the defendant would come forward with evidence and the parties would go back and forth debating the matter. The problem with that notion is that it would reduce antitrust to an economic debate. Under Baxter's view, antitrust would not become the subject of a trial but the subject of a dialogue. Whether or not one agrees that jury trials should be abolished in antitrust cases, if we were to follow the route Baxter proposes, we could even do away with bench trials. In such a world, the facts would not govern; only the laboratory answer to an economic question would. That is not the law, that should not be the law, and so happily we are where we ought to be.

4. Pollock, Vertical Restraints and the Secularization of Antitrust, 75 CALIF. L. REV. 951, 952 (1987).

5. Baxter, supra note 1 , at $948-49$. 
